\title{
Symmetric Linear Assembly of Hourglass-like ZnO Nanostructures
}

Ke Xin Yao, ${ }^{\dagger}$ Romilly Sinclair, ${ }^{\dagger, \ddagger}$ and Hua Chun Zeng ${ }^{\dagger, *}$

${ }^{\dagger}$ Department of Chemical and Biomolecular Engineering, Faculty of Engineering

National University of Singapore, 10 Kent Ridge Crescent, Singapore 119260

${ }^{\ddagger}$ Department of Chemical Engineering, Building 9 West, University of Bath, Claverton Down, Bath, BA2

$7 A Y$, United Kingdom

*Tel: (65) 6516-2896, Fax: (65) 6779-1936, Email: chezhc@nus.edu.sg

\section{SI-1 EDX spectrum of hourglass-like ZnO nanostructures}
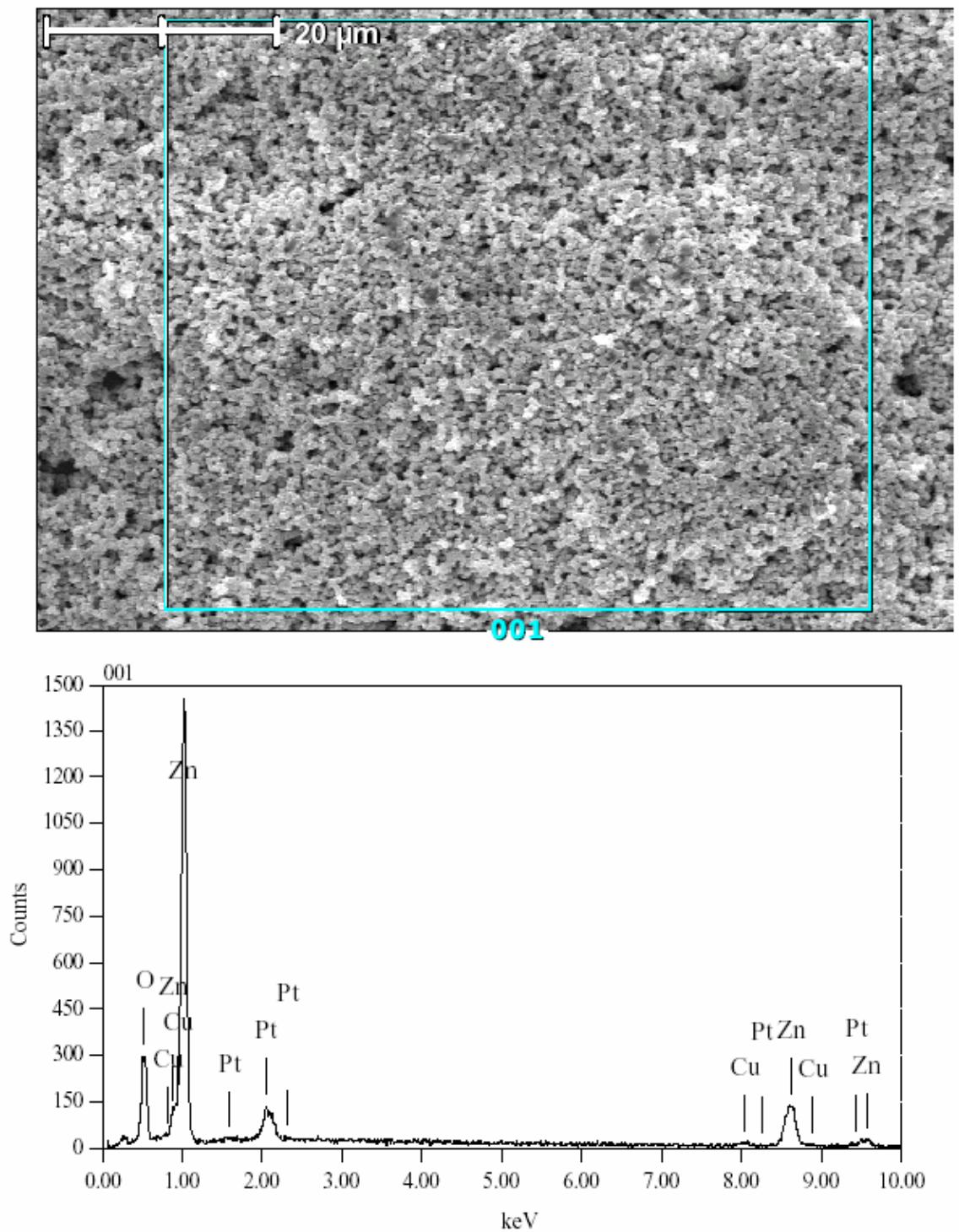

\begin{tabular}{|c|c|c|c|c|c|c|c|c|}
\hline Element & (kev) & masse & Error: & At: & compound & mass: & Cation & $\mathrm{K}$ \\
\hline $0 \mathrm{~K}$ & 0.525 & 17.69 & 0.16 & 49.02 & & & & 18.3091 \\
\hline $\mathrm{Cu} \mathrm{K}$ & 8.040 & 4.10 & 1.23 & 2.86 & & & & 3.8234 \\
\hline $\mathrm{Zn} \mathrm{K}$ & 8.630 & 67.31 & 1.77 & 45.64 & & & & 62.7199 \\
\hline Pt $M$ & 2.048 & 10.89 & 0.60 & 2.47 & & & & 5.9681 \\
\hline Total & & 100.00 & & 100.00 & & & & \\
\hline
\end{tabular}




\section{SI-2 Solid twined nanocrystals of $\mathrm{ZnO}$ (part a)}

The following two TEM images show that the formation of central space depends on the processing time and concentration of ammonia. Under these experimental conditions, the central space has not been formed even though the starting concentration of zinc ions is low (also refer to Figure 3a-c in the main text). Experimental conditions: $40 \mathrm{~mL}$ of a solution (prepared from $0.50 \mathrm{~g}$ $\mathrm{Zn}\left(\mathrm{NO}_{3}\right)_{2} \cdot 6 \mathrm{H}_{2} \mathrm{O}+57 \mathrm{~mL} \mathrm{H} \mathrm{H}_{2} \mathrm{O}+0.30 \mathrm{~mL} \mathrm{NH} \cdot \mathrm{H}_{2} \mathrm{O}$ solution $+16 \mathrm{~mL}$ ethanol $+7 \mathrm{~mL}$ Tween-85) at $220^{\circ} \mathrm{C}$ for $1 \mathrm{~h}$.
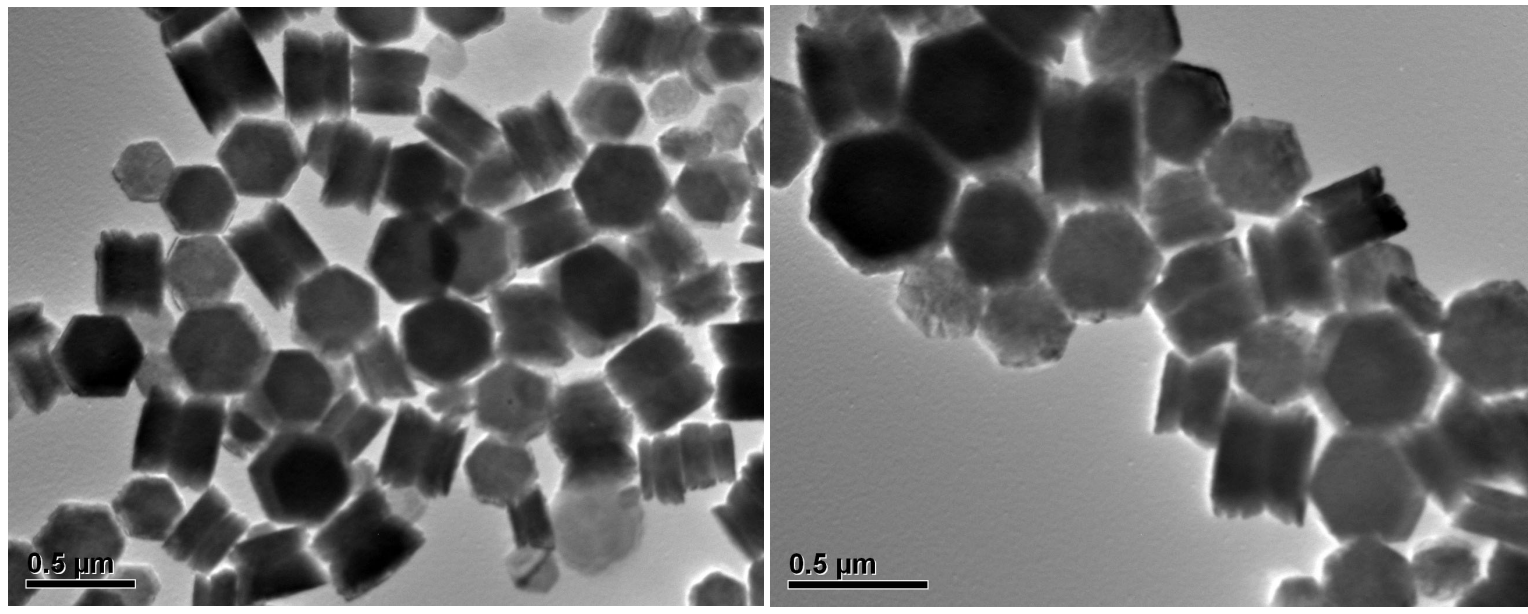

\section{SI-3 Solid twined nanocrystals of $\mathrm{ZnO}$ (part b)}

The following two TEM images show that the formation of central space depends on the processing time and concentration of ammonia. With lesser ammonia in synthesis, the central space cannot be formed even though the starting concentration of zinc ions is low. Instead, much larger microcrystals have been produced owing to a prolonged growth at low temperatures (also refer to Figure 3a-c in the main text). Experimental conditions: $40 \mathrm{~mL}$ of a solution (prepared from $0.45 \mathrm{~g} \mathrm{Zn}\left(\mathrm{NO}_{3}\right)_{2} \cdot 6 \mathrm{H}_{2} \mathrm{O}+57 \mathrm{~mL} \mathrm{H} \mathrm{H}_{2} \mathrm{O}+0.27 \mathrm{~mL} \mathrm{NH} \cdot \mathrm{H}_{2} \mathrm{O}$ solution $+16 \mathrm{~mL}$ ethanol $+7 \mathrm{~mL}$ Tween-85) at $220^{\circ} \mathrm{C}$ for $1 \mathrm{~h}$ and then at $110^{\circ} \mathrm{C}$ for $3 \mathrm{~h}$.
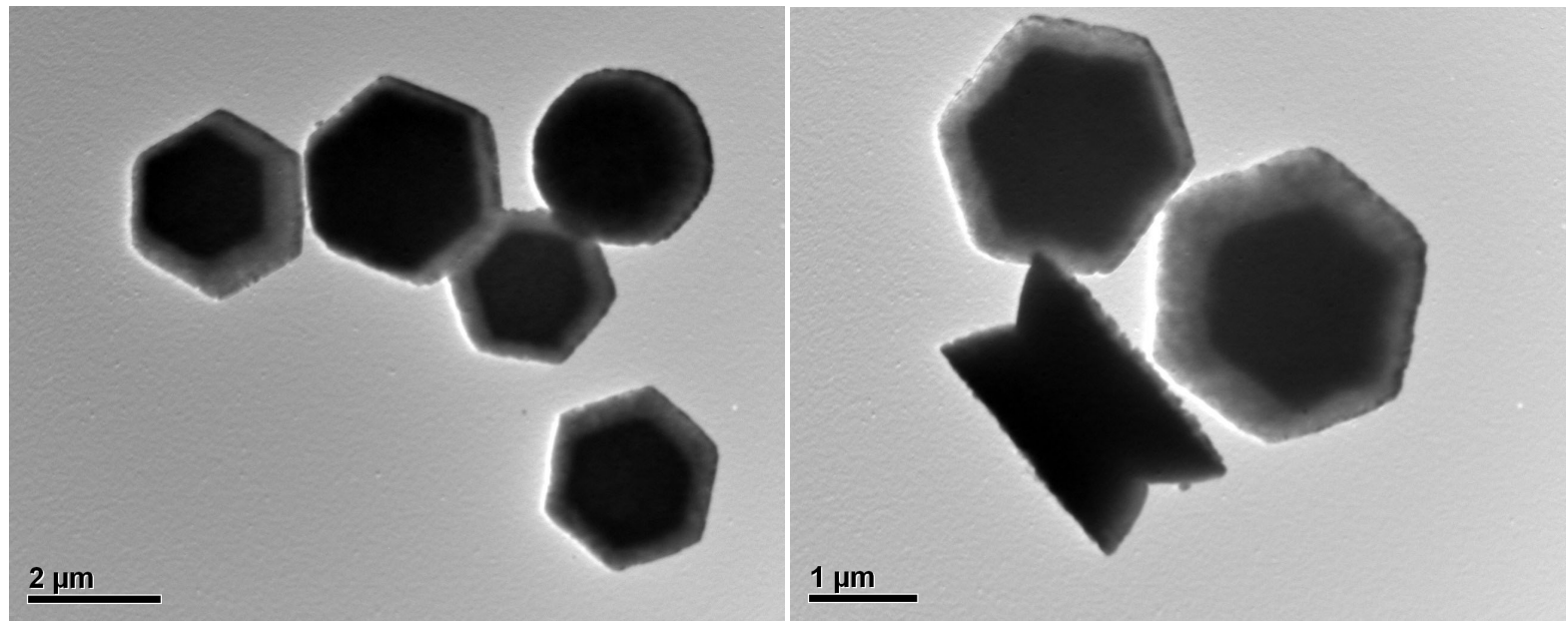


\section{SI-4 Nanorings of $\mathrm{ZnO}$}

Under the condition of low concentration of $\mathrm{Zn}$ ions, the formation of central space becomes easier. The following TEM image shows that some smaller sized complex $\mathrm{ZnO}$ nanostructures were virtually turned into nanorings because of this hollowing process. Experimental conditions: $40 \mathrm{~mL}$ of a solution (prepared from $0.60 \mathrm{~g} \mathrm{Zn}\left(\mathrm{NO}_{3}\right)_{2} \cdot 6 \mathrm{H}_{2} \mathrm{O}+57 \mathrm{~mL} \mathrm{H}_{2} \mathrm{O}+0.36 \mathrm{~mL} \mathrm{NH} \cdot \mathrm{H}_{2} \mathrm{O}$ solution $+16 \mathrm{~mL}$ ethanol $+7 \mathrm{~mL}$ Tween-85) at $180^{\circ} \mathrm{C}$ for $1.5 \mathrm{~h}$.

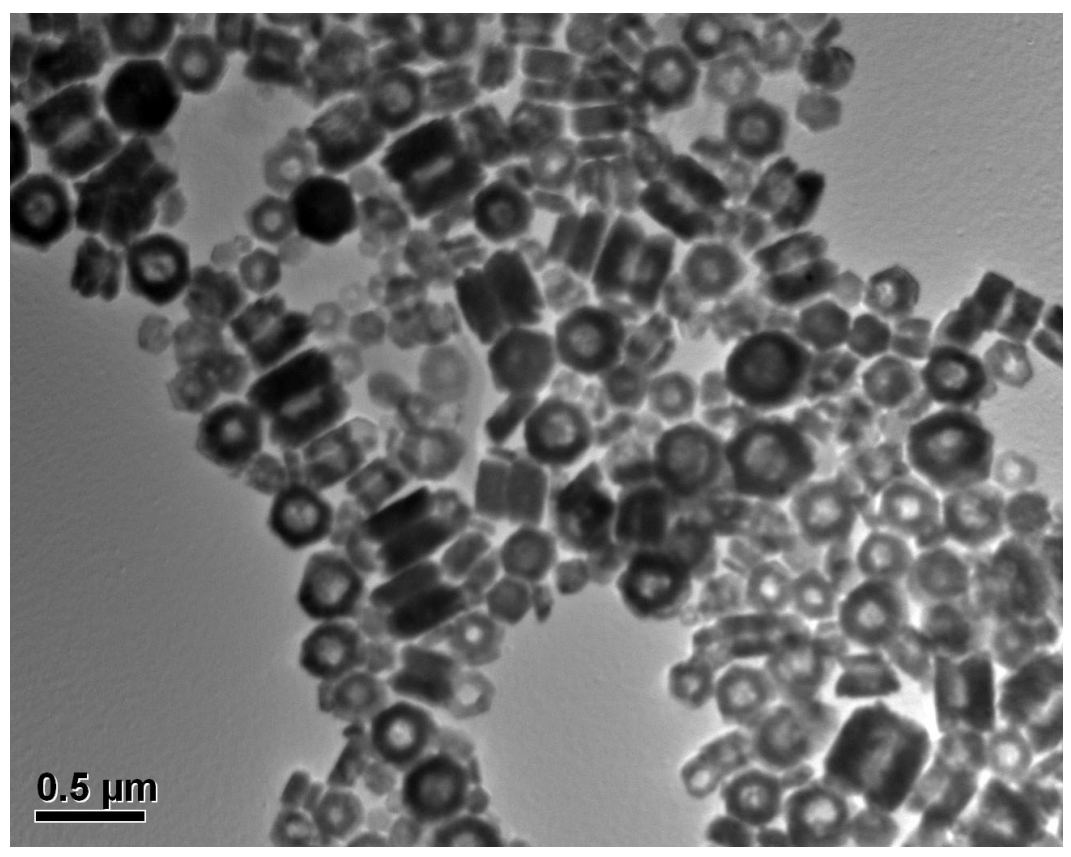

\section{SI-5 Long 1D-assembly of ZnO nanostructures}

The following FESEM image shows that the hourglass-like $\mathrm{ZnO}$ nanostructures can self-arrange into a very long $1 \mathrm{D}$-assembly ( $7.5 \mu \mathrm{m}$ in this case; also refer to Figure $3 \mathrm{~d}-\mathrm{f})$. Experimental conditions: $40 \mathrm{~mL}$ of a solution (prepared from $0.72 \mathrm{~g} \mathrm{Zn}\left(\mathrm{NO}_{3}\right)_{2} \cdot 6 \mathrm{H}_{2} \mathrm{O}+33 \mathrm{~mL} \mathrm{H}_{2} \mathrm{O}+0.432 \mathrm{~mL}$ $\mathrm{NH}_{3} \cdot \mathrm{H}_{2} \mathrm{O}$ solution $+40 \mathrm{~mL}$ ethanol $+7 \mathrm{~mL}$ Tween-85) at $180^{\circ} \mathrm{C}$ for $2 \mathrm{~h}$.

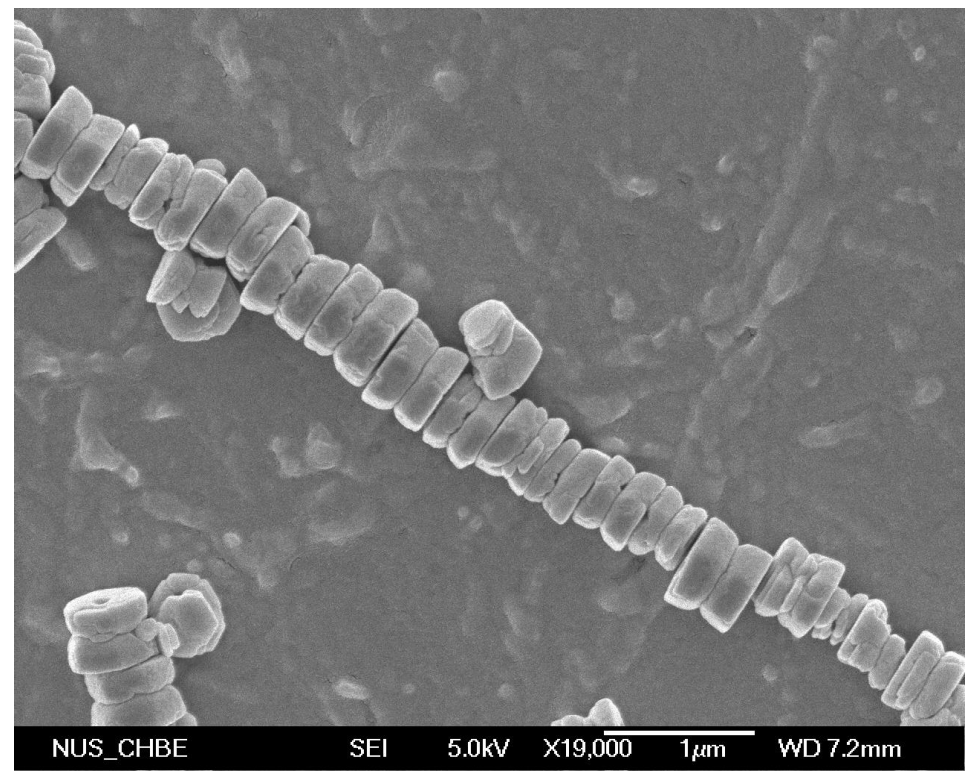




\section{SI-6 Large twined crystals of $\mathrm{ZnO}$ prepared with the same set of precursor chemicals}

The present chemical system allows one to prepared complex structures of $\mathrm{ZnO}$ ranging from nanometer scale (e.g., those reported in the main text) to micrometer scale (e.g., from several micrometers to a few tens of micrometers).

In addition to those reported in the main text, the following two SEM images show two large twined crystals of $\mathrm{ZnO}$ with the (000-1) planes for their common juncture. Experimental conditions: $3.13 \mathrm{~g} \mathrm{Zn}\left(\mathrm{NO}_{3}\right)_{2} \cdot 6 \mathrm{H}_{2} \mathrm{O}+14 \mathrm{~mL} \mathrm{H}_{2} \mathrm{O}+6 \mathrm{~mL} \mathrm{NH}_{3} \cdot \mathrm{H}_{2} \mathrm{O}$ solution $+10 \mathrm{~mL}$ ethanol +2.5 $\mathrm{mL}$ Tween- 85 at $180^{\circ} \mathrm{C}$ for $6 \mathrm{~h}$.

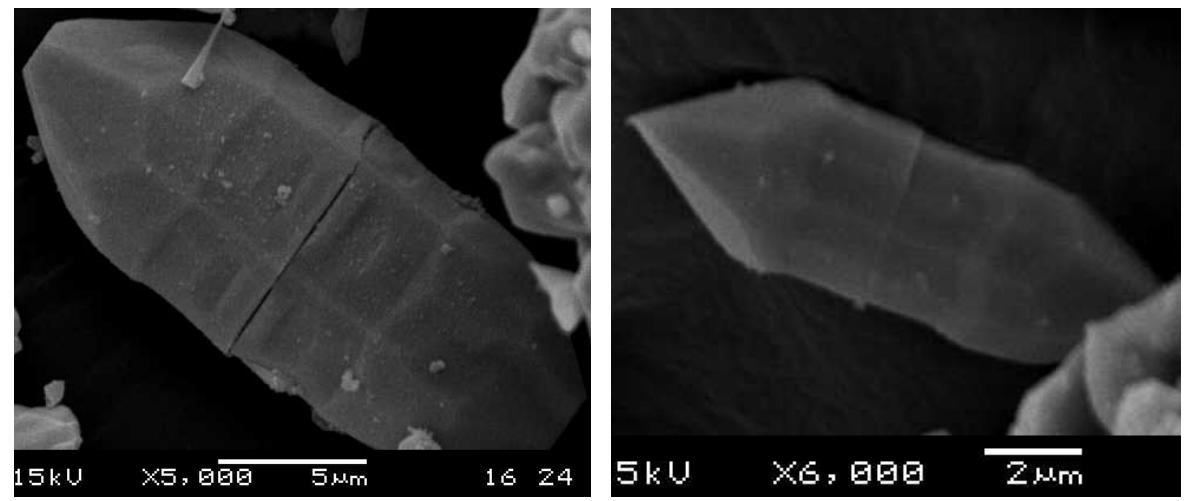

The following three SEM images show some large twined crystals of $\mathrm{ZnO}$ with the (0001) planes for their common juncture, noting the surface features on the faceted crystals (refer to Figure 1 of the main text for these crystal planes). Experimental conditions: (a) $3.13 \mathrm{~g} \mathrm{Zn}\left(\mathrm{NO}_{3}\right)_{2} \cdot 6 \mathrm{H}_{2} \mathrm{O}+14$ $\mathrm{mL} \mathrm{H}_{2} \mathrm{O}+6 \mathrm{~mL} \mathrm{NH} \cdot \mathrm{H}_{2} \mathrm{O}$ solution $+10 \mathrm{~mL}$ ethanol $+2.5 \mathrm{~mL}$ Tween- 85 at $180^{\circ} \mathrm{C}$ for $3 \mathrm{~h}$; (b) $3.50 \mathrm{~g} \mathrm{Zn}\left(\mathrm{NO}_{3}\right)_{2} \cdot 6 \mathrm{H}_{2} \mathrm{O}+13 \mathrm{~mL} \mathrm{H}_{2} \mathrm{O}+7 \mathrm{~mL} \mathrm{NH}{ }_{3} \cdot \mathrm{H}_{2} \mathrm{O}$ solution $+15 \mathrm{~mL}$ ethanol $+2.5 \mathrm{~mL}$ Tween- 85 at $180^{\circ} \mathrm{C}$ for $22 \mathrm{~h}$; and (c) $3.13 \mathrm{~g} \mathrm{Zn}\left(\mathrm{NO}_{3}\right)_{2} \cdot 6 \mathrm{H}_{2} \mathrm{O}+14 \mathrm{~mL} \mathrm{H}_{2} \mathrm{O}+6 \mathrm{~mL} \mathrm{NH}_{3} \cdot \mathrm{H}_{2} \mathrm{O}$ solution $+10 \mathrm{~mL}$ ethanol $+2.5 \mathrm{~mL}$ Tween -85 at $180^{\circ} \mathrm{C}$ for $6 \mathrm{~h}$.
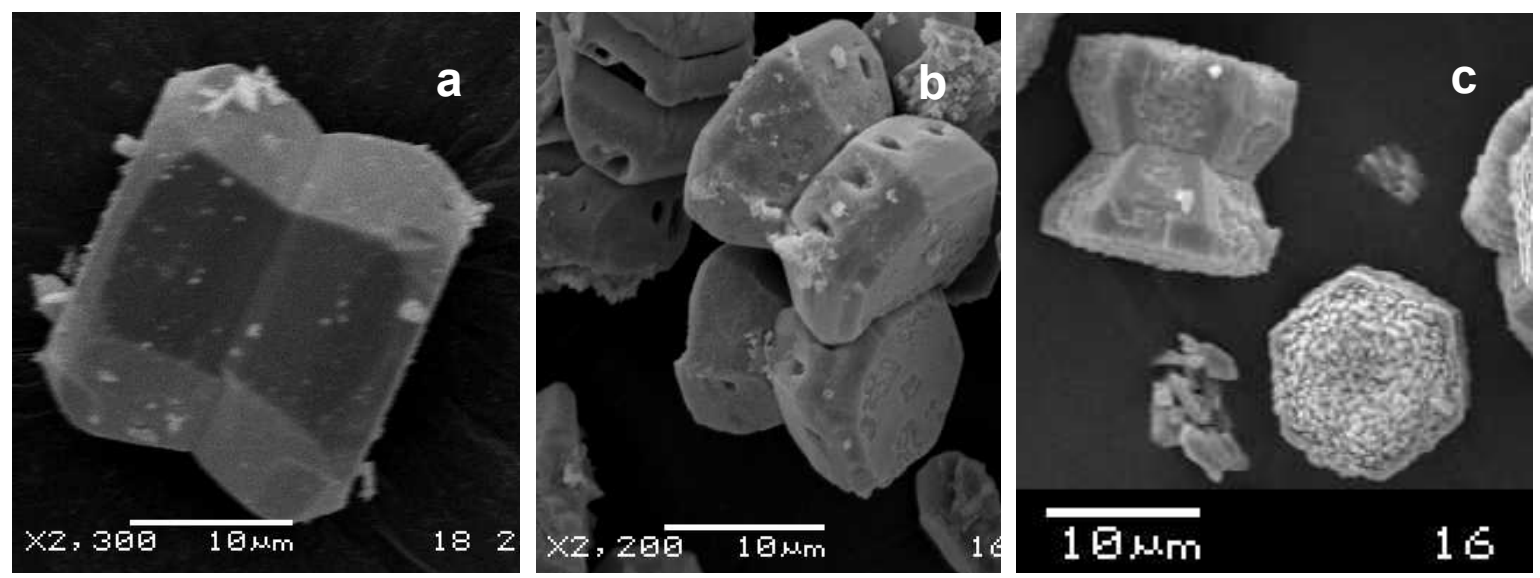